\title{
Identification and characterization of a novel NAC transcription factor gene from triticale ( $x$ Triticosecale Wittmack)
}

\author{
Meng Wang \\ Shihezi University \\ Litong Ren \\ Shihezi University \\ Xiaoyong Wei \\ Shihezi University College of Agriculture \\ Yueming Ling \\ Shihezi University \\ Haitao Gu \\ Shihezi University \\ Shanshan Wang \\ Shihezi University \\ Guagnchao KONG ( $\sim$ kgch001@126.com) \\ Shihezi University https://orcid.org/0000-0002-2637-1374
}

Research Article

Keywords: triticale, TwNAC01, cloning, gene silencing, functional analysis

Posted Date: June 28th, 2021

DOI: https://doi.org/10.21203/rs.3.rs-656711/v1

License: (a) This work is licensed under a Creative Commons Attribution 4.0 International License. Read Full License 


\section{Abstract}

The NAM, ATAF, and CUC (NAC) family of transcription factors plays several important roles in plants, helping to regulate plant growth, development, senescence, and the response to biotic and abiotic stressors. NAC proteins also act as molecular switches, modulating hormonal responses to stress.A novel coding sequence (1059 bp) was cloned from hexaploid triticale. The putative protein encoded by this sequence (352 amino acids) was more than 95\% similar to the amino acid sequence of a NAC protein from Aegilopsis tauschii (goatgrass; XP020161331), and phylogenetic analysis indicated that the novel gene formed a clade with goatgrass, Triticum turgidum, and barley. The novel protein contained a conserved nature actomyosin (NAM) domain (129 consecutive amino acids) between the 20 th and 148 th amino acids at the $\mathrm{N}$-terminus and three transcriptional activation regions at the $\mathrm{C}$-terminus. TwNAC01 was localized to the nucleus. Based on this evidence, the novel gene was identified as a triticale NAC gene and designated TwNAC01 (GenBank accession no. MG736919). After exposure to drought, Macrogol 6000 (PEG6000), $\mathrm{NaCl}$, cold, methyl jasmonate (MeJA), and abscisic acid (ABA), TwNAC01 expression levels were greatest in triticale roots, followed by leaves and stems. Transgenic Arabidopsis thaliana overexpressing TwNAC01 had significantly lower leaf water loss rates and significantly longer roots than wild-type A. thaliana. Virusinduced silencing of the TwNAC01 gene in triticale delayed root development and decreased taproot length. Under drought stress, leaves of TwNAC01- silenced triticale had higher levels of malondialdehyde (MDA) and hydrogen peroxide ( $\mathrm{H} 2 \mathrm{O} 2$ ) than the leaves of the wild type (WT), as well as lower relative water content (RWC), net photosynthetic rate, stomatal conductance, intercellular CO 2 concentration, and transpiration rate.Gene overexpression and silencing experiments suggested that TwNAC01 improves plant stress tolerance by increasing taproot length, regulating the water content of the plant leaves, reducing MAD and $\mathrm{H} 2 \mathrm{O} 2$ content, and adjusting respiration rate.

\section{Introduction}

Triticale ( Triticosecale Wittmack) is a new allopolyploid crop derived from the intergeneric hybridization of wheat (Triticum) and rye (Secale), followed by chromosome doubling (Zilinsky et al., 1974). This crop, which can be used as both a food crop and a forage crop, combines the high grain yield and good quality of wheat with the strong stress resistance of rye (Cao et al., 2011; Sun et al., 2002). Because triticale exhibits strong stress resistance in cultivation, the mining of its resistance genes is important for the molecular breeding of even more stress-resistant triticale varieties.

During growth and development, plants are often affected by a variety of natural adverse environmental factors, such as high temperatures, drought, salinity, and extreme weather. To survive despite these challenges, plants use series of defense mechanisms to resist and tolerate a variety of biotic and abiotic stresses (Cramer et al., 2010; Pinheiro et al., 2011). By binding to cis-acting elements in the target gene promoter, transcription factors act as molecular switches for gene expression, activate or inhibit the expression of target genes, regulate the expression of plant-related genes, and participate in the stress response (Puranik et al., 2012; Nakashima et al., 2012). Many transcription factor families are found in plants, including NAC, WRKY, DREB, and MYB transcription factors (Puranik et al., 2012). Of these, the plantspecific NAC transcription factor family has the most members (Kim et al., 2014; Perez-rodriguez et al., 
2010). Several studies have shown that NAC transcription factors play important roles in a variety of plant processes, including growth and development, leaf decay, hormone increase and decrease, and the regulation of the defense response to biotic and abiotic stresses (Purankik et al., 2012; Nakashima et al., 2012). For example, in Arabidopsis thaliana, overexpression of the AtNAC2 gene improved lateral root elongation (He et al., 2005). In addition, Jensen et al. (2013) reported that Arabidopsis overexpressing ATAF1 showed obvious dwarfism and flowering delay; the endogenous ABA content of the transgenic Arabidopsis overexpressing ATAF1 was also significantly greater than that of the Arabidopsis wild-type (WT; a 6-8-fold increase), which improved the drought tolerance of the transgenic lines. Similarly, overexpression of the OsNAC10 gene, which is specifically expressed in rice roots, increased the diameter of rice roots, improved rice tolerance of drought, and significantly increased rice yield under drought stress (Jeong et al., 2010). Also in rice, the overexpression of the $S N A C 1$ gene improved drought and salt resistance both in the field and in the greenhouse; transgenic plants overexpressing SNAC1 also had lower water loss rates and were more sensitive to ABA than wild-type plants (Xiong et al., 2001). Overexpression of the wheat genes TaNAC2 and TaNAC67 in A. thaliana significantly improved salt, drought, and cold tolerance (Mao et al., 2012). Indeed, RT-PCR analysis showed that TaNAC4 and TaNAC8 were induced by phytohormones (e.g., salicylic acid, SA; methyl jasmonate, MeJA; and abscisic acid, ABA), pathogens (stripe rust), abiotic stressors (salinity and cold), and mechanical injury (Kang et al., 2010). Transgenic wheat overexpressing the TaNAC69 gene had greater biomass and longer roots than the wild type, and thus had a better survival rate under salt and drought stress (Xue et al., 2011). These previous studies demonstrate that NAC genes can be induced by biotic and abiotic stresses under a variety of conditions, and thus are likely to play important roles in plant stress resistance. However, little is known about NAC genes in triticale. To address this knowledge gap, we aimed to identify triticale $N A C$ genes, determine triticale $N A C$ gene function, and provide candidate genes for the molecular breeding of more stress-resistant triticale varieties.

In this study, a novel NAC transcription factor gene, TwNAC01, was cloned from triticale. Gene expression pattern analysis demonstrated that TwNAC01 was upregulated by exposure to drought, $\mathrm{NaCl}, \mathrm{PEG} 6000$, cold $\left(4^{\circ} \mathrm{C}\right), \mathrm{ABA}$, and MeJa. TwNACO1 enhanced tolerance to drought stress in transgenic Arabidopsis and increased taproot length. In $A$. thaliana overexpressing TwNAC01, the water loss rate in the leaves was significantly slower, the physiological indexes of stress resistance were significantly improved, and the taproots were significantly longer as compared to wild-type $A$. thaliana. Compared to the control (CK), triticale carrying the silenced TWNACO1 gene had significantly shorter roots and fewer fibrous roots. The mutant triticale was more sensitive to drought than the control, and also differed from the control with respect to relative water content, hydrogen peroxide $\left(\mathrm{H}_{2} \mathrm{O}_{2}\right)$ content, malondialdehyde (MDA) content, and photosynthetic indexes in the plant leaves.

\section{Materials And Methods}

Plant materials

Seeds produced by the hexaploid triticale variety Xinxiaoheimai 3 were selected and provided by the Wheat Crop Research Institute of Shihezi University (Xinjiang, China). After cleaning and disinfection, the triticale seeds were planted in the drought-stress plot at the Experimental Station of the Agricultural College of 
Shihezi University (Xinjiang, China). To eliminate the effects of natural rainfall, we build a rain shelter over the drought-stress plot before the flowering stage. Plants flowering at the same time were selected during the flowering stage. The control area was irrigated normally. In the drought stress area, irrigation was stopped after the triticale plants reached the heading stage. Both control and experimental plants were visually assessed daily for signs of drought stress. Proline, MDA, electrical conductivity, and chlorophyll levels in the leaves of both sets of plants were also assessed daily as described previously (Chen et al., 2002). During drought stress, proline and MDA levels increased significantly, while soil moisture content levels decreased significantly (Figure S1). When physical indicators of drought stress were observed, the roots, stems, flag leaves, and young grains of both the experimental and control triticale plants were collected.

\section{Full-length 5'- and 3'-RACE}

RNA was extracted from the triticale leaves using Hipure HP Plant RNA Mini Kits (Magen). With these RNA sequences as templates, we performed reverse transcriptase PCR (RT-PCR) to synthesize cDNA sequences using SMARTScribe genome Reverse Transcriptase (TaKaRa, China). Synthesized cDNA was stored at $20^{\circ} \mathrm{C}$ until use. Based on the RNA sequence of Unigene c51971 (708 bp), which was obtained via RNA-Seq sequencing, we designed specific primers for 3'- and 5'-RACE using SMARTer RACE kits (Clonetech; Schedule 1). The RACE procedure was as follows: $94^{\circ} \mathrm{C}$ for $2 \mathrm{~min}, 94^{\circ} \mathrm{C}$ for $30 \mathrm{sec}, 55^{\circ} \mathrm{C}$ for $30 \mathrm{sec}, 72^{\circ} \mathrm{C}$ for $1 \mathrm{~min}, 72^{\circ} \mathrm{C}$ for $35 \mathrm{~min}$, and $16^{\circ} \mathrm{C}$ for $10 \mathrm{~min}$. The PCR products were recovered and purified using $1.0 \%$ agarose gel electrophoresis. The purified PCR products were ligated to the pMD19-T vector (TaKaRa, China) and transformed into TOP010 cells (TIANGEN, China). Positive clones were identified and sequenced. The open reading frame (ORF) of the full-length $\mathrm{CDNA}$ sequence was obtained by splicing the sequencing results using an on-line tool (CAP3;http://doua.prabi.fr/software/cap3) (Shang et al., 2018) and National Center for Biotechnology Information Basic Local Alignment Search Tool (NCBI-BLAST). Sequence alignment analysis

preliminarily identified the sequence as a triticale NAC gene and predicted the positions of the start and stop codons. We then designed a primer pair to amplify the full-length gene (Schedule 1); this gene was preliminarily designated TWNACO1.

Analysis of the triticale TwNACO1 sequence

We used the NCBI ORF Finder (https://www.ncbi.nlm.nih.gov/orffinder/) to identify sequences homologous to the ORF and coding sequences of TWNACO1. We identified conserved structures in the TWNACO1 gene using Smart (http://smart.embl-heidelberg.de/). We analyzed the physical and chemical properties of the predicted TwNAC01 protein, as well as its hydrophobicity, using the ExPASy server (https://web.expasy.org). Multi-alignment of TwNAC01 and other NAC proteins in different species was conducted on DNAMAN. We predicted the subcellular location of the protein using Protcomp and TargetP 1.1

(http://www.cbs.dtu.dk/services/TargetP). The relevant sequences were aligned using MEGA (version 10.0) (Shang et al., 2018) and MegAlign (DNAStar).

Real-time fluorescence quantitative PCR (qPCR) 
The plants to be used for qRT-PCR were cultured at $25^{\circ} \mathrm{C}$ with a normal watering regime, under a $12 \mathrm{~h}$ light/12 $\mathrm{h}$ dark cycle in an artificial climate box. When the seedlings had two leaves and one main shoot, they were transplanted in hydroponic boxes. Three hydroponic boxes were allocated to each treatment; each box had 12 holes, and each hole had 5 seedlings. After transplantation, seedlings were allowed to acclimate for 5 days. After acclimation, one set of boxes was transferred to a cold room $\left(4^{\circ} \mathrm{C}\right)$. Other boxes were treated with one of the following: $1 \mathrm{~L}$ of $20 \%$ PEG6000, $200 \mathrm{mM} \mathrm{NaCl}, 100 \mu \mathrm{M} \mathrm{MeJA}, 100 \mu \mathrm{M} \mathrm{ABA}$. In all treatments, plant roots were soaked and leaves were sprayed with the same solution. Roots and leaves were collected after $0,1,3,6,12$, and $24 \mathrm{~h}$ of treatment. After collection, the materials were frozen in liquid nitrogen and then transferred to a freezer at $-80^{\circ} \mathrm{C}$.

RNA was extracted from the triticale materials collected from each of the six groups [cold $\left(4^{\circ} \mathrm{C}\right)$, drought, 20\% PEG6000, $200 \mathrm{mM} \mathrm{NaCl}, 100 \mu \mathrm{M}$ MeJA, and $100 \mu \mathrm{M}$ ABA using Hipure HP Plant RNA Mini Kits (Magen, China), and cDNA was synthesized using 5XAll-In-One RT MasterMix (abm, Canada) with specific primers (RT-PCR primer pair; Schedule 1). The wheat actin gene was used as internal reference for real-time qPCR (Schedule 1). qPCR was performed using SuperReal PreMixPlus (SYBR Green) kits (Tiangen, China). Each $10 \mu \mathrm{L}$ qPCR volume contained $6 \mu \mathrm{L}$ 2. SuperReal PreMixPlus, $0.25 \mu \mathrm{L}$ forward primer, $0.25 \mu \mathrm{L}$ reverse primer, $1 \mu \mathrm{L}$ cDNA template, and sufficient $\mathrm{ddH}_{2} \mathrm{O}$ to make $10 \mu \mathrm{L}$. qPCR amplifications were performed using a Roche Light-Cycler $480 \mathrm{R}$ with the following cycling conditions: pre-denaturation at $95^{\circ} \mathrm{C}$ for $15 \mathrm{~min}$, followed by 40 cycles of denaturation at $95^{\circ} \mathrm{C}$ for $10 \mathrm{~s}$, annealing at $61^{\circ} \mathrm{C}$ for $30 \mathrm{~s}$, and amplification at $72^{\circ} \mathrm{C}$ for $30 \mathrm{~s}$. All reactions were performed in triplicate, and relative gene expression levels were determined using the $2^{-\Delta \Delta C t}$ method (Livak et al., 2001).

Sub-cellular localization of the TwNAC01 protein

The coding sequence of the TWNACO1 gene was cloned into the plant subcellular expression vector pCAMBIA1301S Enhanced Green Fluorescent Protein (EGFP; GenBank accession no. E17099). Insertion primers containing BamHI-Xbal restriction sites (Schedule 1) were designed and ligated using a ClonExpressll one-step cloning kit (TaKaRa, Dalian, China). After verification via sequencing, the recombinant plasmid and the empty pCAMBIA1301S (EGFP) vector were transformed into Agrobacterium tumefaciens GV3101 (TaKaRa, China) (Mao et al., 2014). A. tumefaciens carrying the recombinant plasmid or the empty vector (TaKaRa, China) were cultured on Luria-Bertani (LB) medium containing Kan + and Rif+. When the OD600 of the bacterial solution was $0.5-0.6$, the bacterial solution was collected and resuspended in infection buffer [ $10 \mathrm{mM} \mathrm{MgCl}_{2}, 10 \mathrm{mM}$ fatty acid methyl ester sulfonate (MES), $150 \mu \mathrm{M}$ surfactant-AS, pH 5.7)].

Subcellular location was visualized in tobacco leaves. Tobacco seeds were planted in an artificial climate box and cultured at $23^{\circ} \mathrm{C}$, with $60 \%$ relative humidity and a $16 \mathrm{~h}$ light $/ 8 \mathrm{~h}$ dark cycle, for 3 weeks prior to vector inoculation. The cultured $A$. tumefaciens solution was then injected into tobacco leaves with $5 \mathrm{~mL}$ needleless sterile syringe, and tobacco seedlings cultured in darkness for 36 hours. Tobacco leaves exhibiting normal growth after inoculation were selected for examination. The area of each selected leaf around the infection site was excised. Enhanced Green Fluorescent Protein (EGFP) fluorescence signals in the tobacco leaves were observed using a Fluo-View confocal microscope (FV300; Olympus, Japan). 
To obtain transgenic Arabidopsis plants, the coding sequence of TwNAC01 containing the termination codon was amplified by RT-PCR and cloned into the Kpnl and Xbal restriction sites of the pCAMBIA1300$35 \mathrm{~S}$ vector (Clontech, TaKaRa, China) under the control of the $35 \mathrm{~S}$ promoter of the cauliflower mosaic virus (CMV). The primers containing the $\mathrm{Kpnl}$ and $\mathrm{Xbal}$ restriction sites are listed in Additional file 2: Table S1. The recombinant vector pCAMBIA1300-35S-TwNAC01 and the empty vector pCAMBIA1300-35S-VC were introduced into A. tumefaciens strain GV3101 (TaKaRa, China). Finally, transgenic Arabidopsis plants were generated using the $A$. tumefaciens-mediated floral dipping method (Clough and Bent et al., 1998). To generate homozygous progeny, T1 and T2 seeds were selected on kanamycin ( $50 \mathrm{mg} / \mathrm{L})$ plates. T3 transgenic $A$. thaliana and wild-type $A$. thaliana plants were watered once at the rosette stage and then subjected to drought stress for 25 days. After 25 days of drought stress, RNA was extracted from the leaves and roots of both transgenic and wild-type $A$. thaliana using Hipure HP Plant RNA Mini Kits (Magen, China). TwNAC01 gene expression levels were then measured using semi-quantitative analysis with gene-specific primers [Table S1; please see the section "Real-time fluorescence quantitative PCR (qPCR)" for details]. Representative lines overexpressing TWNACO1 were used for further analysis.

\section{Drought resistance of transgenic $A$. thaliana overexpressing TwNACO1}

We then measured various stress-related physiological indexes in 35-day-old transgenic $A$. thaliana overexpressing TWNACO1, mock transformed $A$. thaliana (transformed with the empty vector), and wild-type A. thaliana. Leaf relative water content (RWC) was determined following the methods of Flexas et al. (2006), leaf electrical conductivity was determined following Chen Aikui et al. (2010), leaf MDA content was determined following Chen and Wang et al. (2002), and leaf $\mathrm{H}_{2} \mathrm{O}_{2}$ content was determined using an $\mathrm{H}_{2} \mathrm{O}_{2}$ measurement kit (China Nanjing Jiancheng Science and Technology Co., Ltd). We also determined the rate of water loss in the leaves. Five rosette leaves from each group of $A$. thaliana plants (wild-type, empty vector, and the three TwNACO1-overexpression lines) were collected, transferred to filter paper, and placed in a constant temperature incubator at $25^{\circ} \mathrm{C}$. Leaves were weighed every hour for $8 \mathrm{~h}$ and photographed after $2 \mathrm{~h}, 5 \mathrm{~h}$, and $8 \mathrm{~h}$. Water loss was judged based weight loss and on the degree of leaf curl. Water loss rate measurements were replicated six times. After growing for 55 days, plants of all $A$. thaliana lines were carefully removed from the nutrient soil and washed. The length of the main root system of each plant was measured.

Virus-induced gene silencing (VIGS) of the triticale TwNACO1 gene.

Specific primers were designed for the PCR amplification of silencing fragments based on the 3'-UTR region of TWNACO1 gene (Schedule 1), and the barley stripe mosaic virus (BSMV) vector was constructed using ligation-independent cloning (LIC) as previously described (Lee et al., 2015). The BSMV- $\gamma b$ vector was digested with the Apal restriction enzyme and the vector skeleton was recovered. The PCR fragments were treated with T4 DNA polymerase, and the BSMV-rb vectors were digested with the Apal restriction enzyme. A final concentration of $5 \mathrm{mM}$ deoxythymidine triphosphate (dTTP) was added to the carrier reaction system, and the system was allowed to react for $30 \mathrm{~min}$ at room temperature. After the completion of the reaction, 
the system was heated to $75^{\circ} \mathrm{C}$ for $10 \mathrm{~min}$ to inactivate T4 DNA polymerase. The treated fragments (200 $\mathrm{ng}$ ) and the carrier (20 ng) were mixed, heated to $66^{\circ} \mathrm{C}$ for $2 \mathrm{~min}$, and then cooled slowly to room temperature. We transformed $10 \mu \mathrm{l}$ of the mixed product into Escherichia coli using the heat shock method. Positive clones were screened using colony PCR and verified via sequencing. The positive clones were shaken, and the plasmids were extracted for follow-up experiments. The extracted viral vector plasmids were transferred into A. tumefaciens GV3101 for triticale inoculation.

Stress resistance of triticale after TwNACO1 gene silencing.

A. tumefaciens carrying BSMV-phytoene desaturase BSMV::asTaPDS constructs (BSMV-PDS) induce photobleaching or yellow-orange coloration in the silenced tissue due to depletion of enzymes involved in biosynthesis of carotenoid pigments or chlorophyll, respectively (Lee et al., 2015). Thus, these constructs may be used as positive controls for gene silencing. Triticale plants were inoculated with BSMV-PDS, BSMV$\mathrm{yb}$, or BSMV-TWNAC01 for about a week (two to three leaves were treated per plant). After an additional two weeks of growth, white stripes began to appear on the leaves due to the action of the indicator gene. At this point, samples of the leaves were taken and stored at $-80^{\circ} \mathrm{C}$. Total RNA was extracted from these samples for quantitative reverse transcription PCR (qRT-PCR). The RWC of the leaves was determined following the methods of Flexas et al. (2006), MDA content in the leaves was determined following Chen et al. (Chen et al., 2002), and $\mathrm{H}_{2} \mathrm{O}_{2}$ content in the leaves was determined using an $\mathrm{H}_{2} \mathrm{O}_{2}$ measurement kit (Nanjing Jiancheng Science and Technology Co., Ltd). Stomatal conductance, net photosynthesis rate, transpiration rate, and intercellular $\mathrm{CO}_{2}$ concentration were measured using a $\mathrm{LI}-6400$ portable photosynthesis meter ( $\mathrm{Li}$ cor).

Statistical analysis

Microsoft Excel was used for data analysis and Origin and One-way ANOVA was conducted on SPSS Statistics 22.0 software to assess the significant differences. The data were analyzed using Student's $t$ tests; we considered $\mathrm{P}<0.05$ statistically significant.

\section{Result}

The full-length TwNACO1 gene

Using primers designed based on the sequence of Unigene c51971 (GSP-R/F; Schedule 1), we amplified an intermediate sequence from the extracted triticale RNA (Figure S2a) that was 502 bp long (Figure S2b). Based on this intermediate sequence, we used 5'-RACE to amplify the 224 bp $5^{\prime}$ sequence (Figure S2c) and $3^{\prime}$-RACE to amplify the 557 bp 3' sequence (Figure S2d). Splicing of the $3^{\prime}$ and 5 ' sequences based on the intermediate sequence (Unigene c51971), yielded a fill-length ORF of $1059 \mathrm{bp}$. Using specific primers designed based on this sequence, we successfully amplified the gene (Figure S2e). Transformation of this gene fragment into E. coli via the pMD19-T vector confirmed the expression of a 1059 bp sequence (Figure S2f). The predicted amino acid sequence of the gene was $352 \mathrm{bp}$ long and had more than $95 \%$ homology with the NAC amino acid sequences from barley, wheat, and other plants. We thus inferred that the cloned 
gene was a triticale NAC gene, which we designated TwNAC01. This gene has been submitted to GenBank (accession number MG736919).

Gene sequence analysis

A NJ phylogenetic tree based on these highly similar sequences showed that the triticale TwNAC01 protein formed a clade with NAC proteins from Aegilops (XP-020161331), Triticum houdeum (KAE8777325), and Hordeum vulgare (CBZ41151) (Fig. 1a). In particular, the amino acid sequence of TwNAC01 was more than 95\% similar to the wheat (T. aestivum) protein TaNAC20 (KY461026.1) and the Aegilops tauschii protein AtNAC92 (XM020305742.2). The predicted TwNAC01 protein sequence was highly homologous to NAC sequences from barley, wheat, goatgrass, and durum wheat. Sequence alignment revealed that TwNAC01 shared $97.3 \%$ and $83.8 \%$ similarity with that of XP020161331 and KAE87777325,TwNAC01 also belonged to the NAM subgroup(Fig. 1b). The predicted TwNAC01 sequence contained a conserved NAM-superfamily domain composed of 129 consecutive amino acids at the N-terminus (between ammino acid 20 and 148) and three transcriptional activation domains at the C-terminus (Fig. 1c).

Subcellular localization in the nucleus

Localization prediction analysis indicated that the TwNAC01 protein was not located in the chloroplasts or mitochondria. This protein was unlikely to be a chloroplast transport peptide, mitochondrial transport peptide, or signal peptide. The target protein was found in the "_, (in other organelles) secretory pathway. These results, in conjunction with the Protcomp analysis (see section "Analysis of the triticale TwNAC01 sequence"), indicated that predicted protein was located in the nucleus. The shear site was consistent with the predicted upper transmembrane region and signal peptide (Table 1) That is, the shear site was 62 amino acids long with a maximum of 0.113 , and the comprehensive splicing site was 62 amino acids with a maximum value of 0.107 for the signal peptide to show: NO (Table 1 ). In the control group, the EGFP localization signal was dispersed throughout the cell, with the strongest signals originating primarily from the cell membrane and nucleus (Fig. 2). In the treatment group, the EGFP protein signal was restricted to the nucleus (Fig. 2). This suggested that the fusion protein was located in the nucleus, as was predicted by our bioinformatics analysis. 
Table 1

Subcellular localization scores.

\begin{tabular}{|c|c|c|c|c|c|c|}
\hline a Position & cTP & mTP & SP & Other & Loc & TPlen \\
\hline $\begin{array}{l}\text { Positioning } \\
\text { score }\end{array}$ & 0.09 & 0.104 & 0.171 & 0.887 & & 2 \\
\hline b Position & Nucleus & $\begin{array}{l}\text { Cell } \\
\text { membrane }\end{array}$ & Extracellular & Mitochondria & Chloroplast & Bubble \\
\hline $\begin{array}{l}\text { Positioning } \\
\text { score }\end{array}$ & 8.26 & 1.01 & 0.04 & 0.01 & 0.11 & 0.48 \\
\hline
\end{tabular}

Analysis of TwNACO1 gene expression in triticale under stress

The TWNAC01 gene was significantly upregulated $(\mathrm{P}<0.05)$ in triticale roots and grains after drought treatment as compared to the control; TWNAC01 was also upregulated with respect to the control in the stem and leaf tissues, but these differences were not significant (Fig. 3a). This suggested that the triticale TWNACO1 gene was upregulated in response to drought stress, with the strongest upregulation found in the grain, followed by the root, leaf, and stem.

After $24 \mathrm{~h}$ of salinity, MejA, and ABA stress, TwNACO1 was significantly upregulated in the roots as compared to the leaves; in response to these stressors, TwNACO1 expression levels appeared to increase over time (Fig. 3e, 3f). After $1 \mathrm{~h}$ and $24 \mathrm{~h}$ of $\mathrm{NaCl}$ treatment, TwNACO1 expression was significantly more upregulated in the roots than in the leaves (Fig. 3b). In contrast, after $24 \mathrm{~h}$ of cold stress and PEG6000induced dehydration, TWNACO1 was significantly upregulated in the leaves as compared to the roots (although TWNACO1 was significantly upregulated in the roots as compared to the leaves after $12 \mathrm{~h}$ of PEG6000 treatment; Fig. 3d, 3c). This might suggest that the strength of the cold and drought response in the roots increased over time, and that the leaves are more sensitive to cold than the roots. After ABA treatment, TwNAC01 gene expression levels in roots were consistently significantly higher than those in leaves at the same time point (Fig. 3f). Thus, it was likely that the TwNACO1 gene played a role in the stress response of the triticale roots and leaves.

Confirmation of transgenic $A$. thaliana lines overexpressing TwNACO1

PCR analysis of $E$. coli transformed with the pCAMBIA1300-35s overexpression vector recovered $1059 \mathrm{bp}$ band, indicating that transformation had been successful and that the target gene was connected to the vector (Figure S3a). After restriction endonuclease digestion, the vector skeleton (10 kb) and a band slightly longer than 1000 bp were obtained (Figure S3b), indicating that the recombinant expression plasmid containing the target gene had been successfully constructed. The $A$. tumefaciens solution containing the expression vector plasmid was also analyzed using PCR, and a 1059 bp band was recovered (Figure S3c). This indicated that the recombinant plasmid had been successfully introduced into $A$. tumefaciens. After 
the plasmid was introduced into $A$. thaliana inflorescences using the floral dip method, three $T_{0}$ plants expressing TwNAC01 were identified via PCR and 1/2 MS Kan + medium. From these $\mathrm{T}_{0}$ lines, three $\mathrm{T}_{3}$ lines were generated that were confirmed to express TWNACO1.

Root length and leaf water loss rate in transgenic A. thaliana overexpressing TWNACO1

After two hours of drying at $25^{\circ} \mathrm{C}$, the leaves of wild-type $A$. thaliana and those of $A$. thaliana expressing the empty vector had curled slightly, while the leaves of the transgenic $A$. thaliana lines overexpressing TwNACO1 (TwNAC01-1, TwNAC01-2, and TwNAC01-3) exhibited no obvious curling (Fig. 4a). After five hours of drying at $25^{\circ} \mathrm{C}$, the leaves of the wild-type and empty-vector plants were obviously curled, while the leaves of the TwNACO1-overexpression lines were only slightly curled. After eight hours of dehydration, the leaves of the wild-type and empty-vector plants were noticeably withered and crumpled in appearance; although the leaves of the transgenic lines were also somewhat withered, the observed degree of dehydration was much less severe (Fig. 4a). Water loss rate in the wild-type, empty-vector, and transgenic plants increased significantly over time $(\mathrm{P}<0.05)(\mathrm{Fig} .4 \mathrm{~b})$. After one hour of drying, water loss rates were similar across the three lines, and, as drying continued, water loss rates increased linearly in all lines (Fig. 4b). However, for most of the drying time, water loss rates in the transgenic lines were significantly $(\mathrm{P}<$ 0.05) lower than those in the wild-type and empty-vector lines (Fig. 5b). The three transgenic lines had significantly longer roots than the wild-type and empty-vector lines (differences of 1.5-fold and 1.2-fold, respectively; Fig. 5a, 5b).

Physiological indexes of stress resistance in A. thaliana overexpressing TwNACO1

Although the relative leaf water contents of the three transgenic Arabidopsis lines were slightly higher than those of empty-vector and wild-type lines, these differences were not significant (Fig. 6a). However, leaf electrical conductivity (reflecting electrolyte leakage and thus membrane damage) was significantly greater in the empty-vector and wild-type lines as compared to the transgenic lines (Fig. 6b). $\mathrm{H}_{2} \mathrm{O}_{2}$ and MDA levels were significantly greater in the leaves of the wild-type line as compared to all other lines; there were no significant differences in hydrogen peroxide or MDA levels between the empty-vector plants and any of the transgenic lines (Fig. 6c, 6d).

After drought stress, TwNACO1 was upregulated in the roots and leaves of the transgenic plants as compared to the empty-vector and wild-type plants; in all three transgenic lines, TWNACO1 gene expression was significantly greater in the roots than the leaves (Fig. 6e). On average, TwNAC01 gene expression levels in the transgenic $A$. thaliana lines were 8-fold and 38-fold greater than the empty-vector and wild-type plants, respectively. Thus, in response to drought stress, TwNAC01 was upregulated in transgenic A. thaliana overexpressing TwNAC01 as compared to mock-transformed and wild-type A. thaliana.

Expression of TWNACO1 after VIGS in triticale under drought stress

A 327 bp sequence was amplified using the VIGS primers (Figure S4a, Fig. 5). After transformation of the amplified sequence into $E$. coli, positive clones were identified via PCR amplification (Figure S4b, S4c). After drought stress, TwNAC01 gene expression levels in the control plants were significantly greater than those 
in the TwNAC01-silenced plants (BSMV-TwNAC01). In contrast, drought stress significantly upregulated TwNAC01 in the empty-vector (BSMV- $\gamma b$ ) and indicator-gene (BSMV-PDS) plants as compared to the control plant. This indicated that drought stress upregulated the triticale TWNACO1 gene; after TWNACO1 gene silencing, TWNACO1 was downregulated, even under drought conditions (Fig. 7).

Phenotypic implications of TWNACO1 gene silencing in triticale

About two weeks after inoculation with the BSMV vectors, the indicator-gene (BSMV-PDS) plants began to exhibit symptoms of stripe mosaic virus. At 20 days after inoculation, large areas of the leaves of these plants were bleached, while the leaves of empty-vector (BSMV- $y b$ ) and TwNAC01-silenced (BSMVTwNAC01) plants showed slight bleaching (Fig. 8a). In general, the growth potential of each of the inoculated groups (BSMV- $\gamma b$, BSMV-PDS, and BSMV-TwNAC01) was weaker than that of the control group (Fig. 8b, 8c). The mean RWC of the leaves of BSMV-TwNAC01 was significantly lower than that of the leaves of the CK (Fig. 8d). The roots of the TwNAC01-silenced plants were significantly shorter than those of the control, empty-vector, and indicator-gene plants (Fig. 8e, 8f). This suggested that the TwNAC01 gene substantially affects triticale root growth, and that TwNAC01 gene silencing inhibits triticale root development. This showed that silencing the TWNACO1 gene significantly reduced triticale growth.

Physiological indexes of drought stress and photosynthesis in TwNACO1-silenced triticale

After drought stress, levels of $\mathrm{H} 2 \mathrm{O} 2$ and MDA in the leaves of BSMV-TwNAC01 plants were significantly higher than those in the leaves of uninfected control plants (Fig. 9a, 9c), while RWC was significantly lower (Fig. 9b). This demonstrated that the triticale leaves were more stressed by drought when the TwNAC01 gene was silenced. That is, the stress-resistance ability of the plant decreased after TwNAC01 gene silencing. This suggested that TwNAC01 played an important role in triticale stress resistance.Net photosynthetic rate, stomatal conductance to $\mathrm{H}_{2} \mathrm{O}$, intracellular $\mathrm{CO}_{2}$ level, and transpiration rate were significantly lower in the BSMV-TwNAC01 leaves as compared to the control (Fig. 9d-g); net photosynthetic rate and intracellular $\mathrm{CO} 2$ level were significantly lower than the control in the BSMV-yb and BSMV-PDS leaves (Fig. 9d, 9f), while transpiration rate was significantly lower than the control in the BSMV-PDS leaves (Fig. 9g). Net photosynthetic rate (Fig. 9d), stomatal conductance (Fig. 9e), intercellular $\mathrm{CO}_{2}$ concentration (Fig. 9f), and transpiration rate (Fig. 9g) of control, BSMV-yb, BSMV-PDS, and BSMV-TwNAC01 triticale leaves decreased gradually as drought stress increased. Thus, TwNAC01 gene silencing significantly affected photosynthesis-related indexes in the leaves of BSMV-infected plants subjected to drought stress, again demonstrating that TwNACO1 silencing weakened the stress resistance of triticale.

\section{Discussion}

NAC transcription factors are considered the most important family of transcription factors in plants; these transcription factors play various important roles in the stress response, as well as in the regulation of plant growth and development (Xu et al., 2015). Stress-related NAC transcription factors have been well examined in wheat, rice, and Leymus triticoides, but relatively few studies have explored stress-related NAC transcription factors in allohexaploid triticale. Here, we used RACE RNA-seq and RT-PCR to clone the first 
putative NAC gene from heterohexaploid triticale. This putative NAC gene had more than $95 \%$ similarity with known NAC genes from other crops, including common wheat, goatgrass, and durum wheat. The molecular formula of the encoded protein was predicted to be $\mathrm{C}_{1722} \mathrm{H}_{2642} \mathrm{~N}_{464} \mathrm{O}_{522} \mathrm{~S}_{19}$, with a predicted molecular weight of $38805.86 \mathrm{M}_{r}$, and a theoretical isoelectric point of 5.44. The total number of positive/negative charge residues predicted in this protein were $46 / 37$, and the atomic composition was $\mathrm{C}_{1722}, \mathrm{H}_{2642}, \mathrm{~N}_{464}$, $\mathrm{O}_{522}$, and $\mathrm{S}_{19}$, The extinction coefficient of the predicted protein was 46,996 , and its absorbance at a wavelength of $280 \mathrm{~nm}$ was $1.211 \mathrm{~L} /(\mathrm{g} \cdot \mathrm{cm})$. The total average hydrophobic coefficient of the predicted protein was -0.494 , indicating that the putative protein was hydrophilic. These findings were consistent with our phylogenetic analysis. In addition, the predicted protein sequence of the putative NAC gene included a conserved NAM domain between the 20th and 148th amino acids at the N-terminus, as well as three transcriptional activation regions at the $\mathrm{C}$-terminus. We thus concluded that the putative gene was indeed an NAC gene. This gene was designated TWNACO1.

Our results showed that TWNACO1 was upregulated by a variety of abiotic stressors and signal molecules, including salinity, drought, PEG6000, and ABA. Several studies have shown that about $20-25 \%$ of plant NAC genes respond to stress treatments and participate in stress alleviation (Puranik et al., 2012; Nuruzzaman et al., 2010; Fang et al., 2008). In addition, A. thaliana overexpressing the wheat NAC genes TaNAC2 and TaNAC67 exhibited significantly improved tolerance of drought, salinity, and cold as compared to the wild-type (Mao et al., 2014). Similarly, the overexpression of wheat NAC genes (TaNAC2a, TANAC4a, TaNAC6, TaNAC7, TaNAC13, and TaNTL5) in tobacco significantly improved drought tolerance (Tang et al., 2012). Previous studies have also shown that NAC gene expression increases in response to drought stress (Wu et al., 2009; Chen et al., 2014; Nakashima et al., 2007). Consistent with this, TwNACO1 expression was significantly upregulated in the drought-stressed plant roots and young grains as compared to the unstressed controls. This suggested that TwNACO1 expression is induced by drought stress, and that this gene plays an important role in the response to drought in triticale. NAC genes have also been shown to be upregulated in aging plant tissues, by treatment with plant signal molecules (e.g., ABA, ethephon, JA, and SA) (Jensen et al., 2010; Tang et al., 2012; Bu et al., 2008; Xia et al., 2010), and by exposure to ethylene and methyl jasmonate (Scharrenberg et al., 2003). Here, the upregulation of TWNAC01 in response to ABA and various abiotic stressors indicated that the abiotic stress process may be regulated by the ABA hormone in triticale.The upregulation of TWNACO1 in response to stress was stronger in the roots as compared to the leaves, consistent with a previous study, which showed that TaNAC4 was more strongly upregulated in wheat roots as compared to leaves and stems (Xian et al., 2010). This suggested that TwNAC01 will be overexpressed in triticale roots first in response to stress, in order to promote the development of plant roots and reduce the damage caused by adverse conditions.

The mechanisms by which NAC transcription factors alleviate drought stress in plants have been well studied. For example, the overexpression of the NAC gene ATAF1 in A. thaliana decreased transpiration rate and increased drought tolerance (Christiansen et al., 2011). Similarly, rice overexpressing OsNAP had lower water loss rates during vegetative growth, increased sensitivity to exogenous $A B A$, and improved tolerance of salt, drought, and low temperature stress (Negi et al., 2018). Also in rice, NAC transcription factors regulate the expression of OSSRO1c genes, which are primarily expressed in guard cells; the overexpression 
of OsSRO1C increases $\mathrm{H}_{2} \mathrm{O}_{2}$ accumulation in guard cells and reduces the number of completely open stomata, thus reducing water loss via transpiration (You et al., 2013). Finally, the SNAC3 gene in rice targets a ROS-scavenging gene, and SNAC3 overexpression upregulates this target gene (Fang et al., 2015). These previous results suggest that, when plants are under stress, the NAC gene can reduce transpiration rate by promoting plant root elongation, improving $\mathrm{H}_{2} \mathrm{O}_{2}$ and $\mathrm{MAD}$ accumulation, and increasing leaf water content. Ultimately, these factors enhance plant adaptability to adversity. Here, TwNACO1 expression was successfully silenced in triticale BSMV-TwNACO1 plants: TWNACO1 expression levels in the triticale BSMVTWNACO1 plants were significantly lower than those in the control, BSMV- $y b$, and BSMV-PDS plants. In general, the growth potential of the TwNACO1-silenced plants was significantly lower than that of the other lines. In particular, the TWNAC01-silenced plants had shorter roots and reduced water content as compared to the other plants. Under drought conditions, markers of physiological stress (i.e., MDA and $\mathrm{H}_{2} \mathrm{O}_{2}$ levels) were significantly increased in TwNAC01-silenced plants as compared to the controls, while relative water content and markers of photosynthetic activity (net photosynthetic rate, stomatal conductance, transpiration rate, and intercellular $\mathrm{CO}_{2}$ concentration) were significantly reduced. The observed changes in these physiological indexes suggested that triticale growth and stress resistance were substantially impaired by TWNACO1 silencing.

In Conclusion, The overexpression of the triticale TwNAC01 gene in A. thaliana improved the drought resistance of $A$. thaliana by increasing the water retention capacity of the leaves, reducing cellular membrane damage, decreasing the production of ROS in the leaves, and promoting root elongation. In TwNAC01-silenced triticale, leaf relative water content and the root length were significantly decreased as compared to the control, while leaf $\mathrm{H}_{2} \mathrm{O}_{2}$ and MDA levels were significantly increased. Leaf net photosynthetic rate, stomatal conductance, intercellular $\mathrm{CO}_{2}$ concentration, and transpiration rate were also significantly lower in the TWNACO1-silenced plants as compared to the control. These results indicated that TwNACO1 silencing decreased the drought resistance of triticale, suggesting that the TWNACO1 gene plays an important role in the response of triticale to drought stress.

\section{Declarations}

\section{Declaration of competing interest}

The authors declare that they have no known competing financial interests or personal relationships that could have appeared to influence the work reported in this paper.

\section{Author Contributions}

GK planned and designed the research and wrote the main manuscript text; MW performed most of the experiments and data acquisition; LR, XW, HG, SY and YL helped with experiments and data analysis; MW participated in figure preparation and manuscript organization. All the authors agreed on the contents of the paper and declare no conflicts of interest. 


\section{Acknowledgements}

This study was supported by the National Natural Science Foundation of China $(31860376,31360333)$ and a Ministry of Agriculture 948 project (2013-Z75).

\section{References}

Aida, M., Ishida, T., Fukaki, H., Fujisawa, H., Tasaka, M., 1997. Genes involved in organ separation in Arabidopsis:an analysis of the cup-shaped cotyledon mutant. Plant Cell. 9:841-857.

Bu, Q., Jiang, H., Li ,C.B., et al. 2008. Role of the Arabidopsis thaliana NAC transcription factors ANAC019 and ANAC055 in regulating jasmonic acid-signaled defense responses. Cell Res. 18 (7): 756-767.

Cao, L.Z., Kong,G.C., 2011. Research and Application of Physiology Ecology and Genetics of Triticale. Economic Management Press: Beijing.

Chen, J.X.,Wang, X.F., 2002. Plant Physiology Experiment Guide . Guangzhou: South China University of Technology Press. 124.

Chen,X., Wang, Y.F., Lv, B., Li, J., Luo, L.Q., Liu S.C., Zhang, X., Ma, H., Ming, F., 2014. The NAC family transcription factor OsNAP confers abiotic stress response through the ABA pathway. Plant Cell Physiology. 55(3): 604-619.

Christiansen, M.W., Holm ,P.B.,Grehersen, P.L., 2011. Characterization of barley (Hordeum vulgare L.) NAC transcription factors suggests conserved functions compared to both monocots and dicots. BMC Research Notes. 4(1): 302.

Clough, S.J., Bent, A.F., 1998. Floral dip: a simplified method for Agrobacterium-mediated transformation of Arabidopsis thaliana. Plant J.16 (6): 735-743.

Cramer, G.R., 2010. Abiotic stress and plant responses from the whole vine to the genes. Aust J Grape Wine Res. 16, 86-93.

Fan, B., Sun, X.B., Zhang, Y.B., Zhang, X., Yuan, J.B., Zhang, H.L., Xiao, W.Y., Han L.B., Xu, L.X., 2016. Cloning and expression analysis of ZjCCS from Zoysia Japonica. Acta Agrestia Sinica. 24(2):239-245.

Fang, L., Su, L., Sun, X., Li, X., Sun, M., Karungo, S.K., Fang, S., Chu, J., Li, S., Xin, H., 2016. Expression of vitis amurensis NAC26 in Arabidopsis enhances drought tolerance by modulating jasmonic acid synthesis, J. Exp. Bot. 67(9): 2829-2845.

Fang, Y., You, J., Xie, K., 2008. Systematic sequence analysis and identification of tissue-specific or stressresponsive genes of NAC transcription factor family in rice. Mol Genet Genomics. 280 (6): 547-563.

Fang, Y.J., Liao, K. F., Du, H., et al.2015. A stress-responsive NAC transcription factor SNAC3 confers heat and drought tolerance through modulation of reactive oxygen species in rice. Journal of of Experiment 
Botany. 66: 6803-6817.

Flexas, J., Ribas-Carb, S., Bota, J.囚et al『2006. Decreased rubi-sco activity during water stress is not induced by de-creased relative water content but related to conditions oflow stomatal conductance and chloroplast $\mathrm{CO}_{2}$ concentra-tion.New Phytologist.172(1) : 73-82区

Fujita, M., Fujita, Y., Maruyama, K., et al. 2004. A dehydration-induced NAC protein, RD26, is involved in a novel ABA-dependent stress-signaling pathway. Plant J. 39 (6): 863-876.

GhPHOT2 in chloroplast avoidance of Gossypium hirsutum. Plant Physiol. \& Biochem. 135.

He, X.J., Mu, R.L., Cao,W.H., Zhang,Z.G., Zhang,J.S., Chen, S.Y., 2005. At NAC2, a transcription factor downstream of ethylene and auxin signaling pathways, is involved in salt stress response and lateral root development. Plant J. 44: 903-916.

Holst-Jensen, A., Rønning, SB., Løvseth, A., et al. 2003. PCR technology for screening and quantification of genetically modified organisms (GMOs).Anal Bioanal Chem. 375:985-993.

Hong, Y., Zhang, H., Huang, L., Li, D., Song, F., 2016. Overexpression of a stress-responsive NAC transcription factor gene ONAC022 improves drought and salt tolerance in rice. Front.Plant Sci. 7: 4.

Hu, H.H., Dai, M.Q., Yao, J.L., et al. 2006. Overexpressing a NAM, ATAF, and CUC (NAC) transcription factor enhances drought resistance and salt tolerance in rice Proceedings of the National Academy of Sciences of the United States of America. 103: 12987-12992.

Jensen, M. K., Lindemose, S., Masi, F., et al. . 2013. ATAF1 transcription factor directly regulates abscisic acid biosynthetic gene NCED3 in Arabidopsis thaliana. FEBS Open Bio3. 321-327.

Jensen, M.K., Kjaers, gaard.T., Nielsen, M.M., et al. 2010. The Arabidopsis thaliana NAC transcription factor family: structure-function relationships and determinants of ANAC019 stress signalling . Biochem J. 426 (2): 183-196.

Jensen, M.K., Rung, J.H., Gregersen, P.L., et al. 2007.The Hv NAC6 transcription factor: a positive regulator of penetration resistance in barley and Arabidopsis. Plant Mol Biol, 65:137-150.

Jeong, J.S., Kim, Y.S., Baek, K.H., et al. 2010. Root-specific expression of OsNAC10 improves drought tolerance and grain yield in rice under field drought conditions. Plant Physiol. 153, 185-197.

Kang, S.G., Price, J., Lin, P.C., Hong, J.C. Jang, J.C., 2010. The arabidopsis bZIP1 transcription factor is involved in sugar signaling, protein networking, and DNA binding. Mol Plant. 3: 361-373.

Kim, CK., Chung, J.D, Park, S.H., Burrell, A.M, Kamo, K.K, 2004. Byrne DH.Agrobacterium tumefaciensmediated transformation of Rosa hybridausing the green fluorescent protein (GFP) gene. Plant Cell Tissue Organ Cult. 78(2):107-11. 
Kim, T-H., 2014. Mechanism of ABA signal transduction:Agricultural highlights for improving drought tolerance. Journal of Plant Biology. 57 (1): 1-8.

Kjaersgaard, T., Jensen, M.K., Christiansen, M.W., Gregersen, P., Kragelund, B.B., Skriver, K., 2011. Senescence-associated barley NAC (NAM, ATAF1, 2, CUC) transcription factor interacts with radical-induced cell death 1 through a disordered regulatory domain. J Biol Chem. 286: 35418-35429.

Ko, J.H, Yang, S.H, Park, A.H, et al. 2007. ANAC012, a member of the plant-specific NAC transcription factor family, negatively regulates xylary fiber development in Arabidopsis thaliana. Plant J. 50(6):1035-1048.

Lee, W., J.J. Rudd., K. Kanyuka., 2015.Virus induced gene silencing (VIGS) for functional analysis of wheat genes involved in Zymoseptoria tritici susceptibility and resistance.Fungal Genetics and Biology. 79: p. 8488 .

Lee, W.S., Hammond-Kosack, K.E., Kanyuka, K., 2012. Barley stripe mosaic virus-mediated tools for investigating gene function in cereal plants and their pathogens: virus-induced gene silencing, hostmediated gene silencing, and virus-mediated overexpression of heterologous proteins. Plant Physiol. 160,582-590.

Livak, K.J, Schmittgen, T.D.2001. Analysis of relative gene expression data using real-time quantitative PCR and the $2^{-\Delta \Delta}$ CTmethod. Methods. 25(4):402-8.

Mao, X., Chen, S., LI, A., et al. 2014. Novel NAC transcription factor TaNAC67 confers enhanced multi-abiotic stress tolerances in Arabidopsis.PLo S ONE. 9 (1): e84359.

Mao, X.G., Zhang, H.Y., Qian, X.Y., Li, A., Zhao, G.Y., Jing, R.L., 2012. Ta NAC2, a NAC-type wheat transcription factor conferring enhanced multiple abiotic stress tolerances in Arabidopsis. J Exp Bot. 63: 2933-2946.

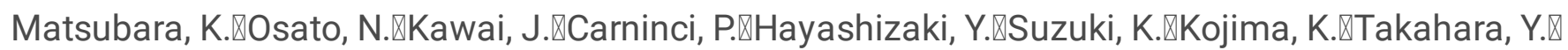
Yamamoto, K., Kikuchi, S., 2003.Comprehensive analysis of NAC family genes in Oryza sativa and Arabidops isthafiana.DNARes.10®239®247.

Nakashima, K., Takasaki, H., Mizoi, J.,etal. 2012. NAC transcription factors in plant abiotic stress responses. Biochim Biophys Acta. 1819 (2): 97-103.

Nakashima, K., Tran, L.S. Van, Nguyen. D., et al. 2007. Functional analysis of a NAC-type transcription factor OsNAC6 involved in abiotic and biotic stress-responsive gene expression in rice. Plant Journal. 51, 617-630.

Negi, S., Tak, H., Ganapathi, TR., et al. 2018. A banana NAC transcription factor (MusaSNAC1) imparts drought tolerance by modulating stomatal closure and $\mathrm{H}_{2} \mathrm{O}_{2}$ content. Plant Molecular Biology. 96: 457-471.

Nuruzzaman, M., Manimekalai, R., Sharoni, A. M., et al. 2010. Genome-wide analysis of NAC transcription factor family in rice. Gene. 465, 30-44. 
Olsen, A.N., Ernst, H.A., Leggio, L.L., et al. 2005. NAC transcription factors: structurally distinct, functionally diverse. Trends in Plant Science. 10(2): 79-87.

Perez-Rodriguez, P., Riano-Pachon, D.M., Correa, L.G., 2010 . PIn TFDB: updated content and new features of the plant transcription factor database. Nucleic Acids Res. 38,D822-D827.

Pinheiro, C., Chaves, M.M., 2011. Photosynthesis and drought: can we make metabolic connections from available data. J Exp Bot62 (3): 869-882.

Puranik, S., Sahu, PP., Srivastava, P.S., Prasad,M., 2012. NAC proteins: regulation and role in stress tolerance. Trends Plant Sci. 17(6):369-81.

Scharrenberg, C., Falk, J., Quast, S., et al. 2003. Isolation of senescence-related cDNAs from flag leaves of field grown barley plants. Physiologia Plantarum. 118:278-288.

Shan, W., Chen, J.Y., Kuang, J.F., Lu, W.J., 2016. Banana fruit NAC transcription factor MaNAC5 cooperates with MaWRKYs to enhance the expression of pathogenesis-related genes against Colletotrichum musae. Mol Plant Pathol. 17(3): 330-338.

Shang, B., Zang, Y., Zhao, X., Zhu, J., Zhang, X., 2018. Functional characterization of

Souer, E.Van., Houwelingen, A., Kloos, D, Mol, J., Koes, R. 1996. The noapical meristem gene of Petunia is required for pattern formation in embryos and flowers and is expressed at meristem and primordia boundaries. Cell. 85:159-170.

Sun, Yuanshu., Research and Application of Chinese Triticale Genetic Breeding. 2002. Zhejiang Science and Technology Press: Hangzhou

Takashi, K., Taga, Y., Takai, R., I.M., Mastsui, H., Takayama, S., Isogai, A., Che, F.S., 2009. The transcription factor OsNAC4 is a key positive regulator of plant hypersensitive cell death. EMBO Journal. 28: 926-936.

Tang, Y., Liu, M., Gao, S., et al. 2012. Molecular characterization of novel TaNAC genes in wheat and overexpression of TaNAC2a confers drought tolerance in tobacco. Physiol Plant. 144 (3): 210-224.

Wu, Y., Deng, Z., LAl, J., et al. 2009. Dual function of Arabidopsis ATAF1 in abiotic and biotic stress responses . Cell Research. 19 (11): 1279-1290.

Xia, N., Zhang, G., Liu, X.Y., et al. 2010. Characterization of a novel wheat NAC transcription factor gene involved in defense response against stripe rust pathogen infection and abiotic stresses. Mol Biol Rep. 37, 3703-3712.

Xiong, L., Ishitani, M., Lee, H., Zhu, J.K., 2001.The Arabidopsis LOS5/ABA3 locus encodes a molybdenum cofactor sulfurase and modulates cold stress and osmotic stress-responsive gene expression. Plant Cell. 13: 2063-2083. 
Xu, et al. 2015.Wheat NAC transcription factor TaNAC29 is involved in response to salt stress . Plant Physiology and Biochemistry. 96, 356-363.

Xu, L., Liu, SH.Y., Yu, M., Liu, H.ZH., 2014. Research progress on common plant transgenic technologies and methods.Northern Horticulture. (20):184-188.

Xue, G.P., Way, H.M., Richardson, T., Drenth, J., Joyce, P.A. Mcintyre C. L., 2011. Overexpression of Ta NAC69 leads to enhanced transcript levels of stress up-regulated genes and dehydration tolerance in bread $\mathrm{w}$ heat. Mol Plant. 4: 697-712.

You, J., Zong, W., Li, X, K., et al. 2013. The SNAC1-targeted gene OsSRO1c modulates stomatal closure and oxidative stress tolerance by regulating hydrogen peroxide in rice. Journal of Experiment Botanny. 64: 569583.

Yu, H.X., Luo, C., Xu, C., He, X.H., 2016. Molecular cloning and expression analysis of a NAC transcription factor from mango. Molecular Plant Breeding. 14(1): 38-44.

Zillinsky, F .J., 1974. The development of triticale. Adv Agron. 26:315-348.

\section{Figures}


a

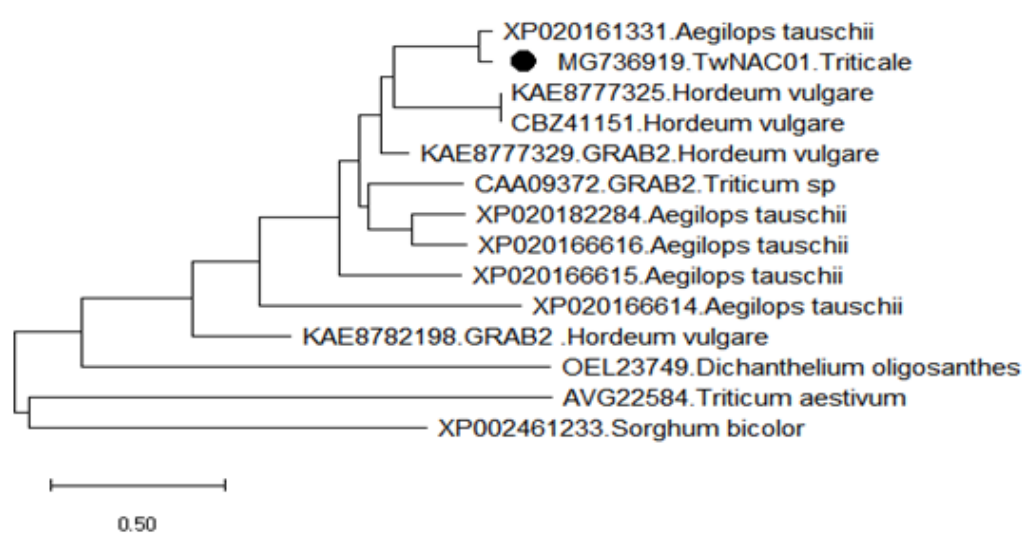

b XP020161331. CB241151.

KAE8777329. MG736919.

Consensus

XP020161331.

KADS777325.

CBQ41151.

XPES 0182284.

MG736919.

consensus

XP020161331.

KAE8777325.

CB841151.

XP020182284.

MG736919.

Consensus

XPC20161331.
KAD 8777325.

KAD8777325.

KAD8777329.

XPC20182284.

MG736919.

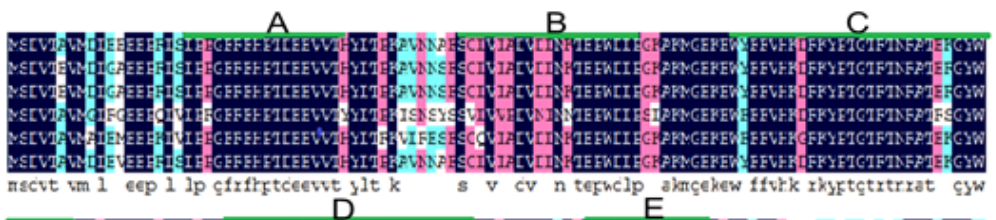

B

100

100

100
100

100
100
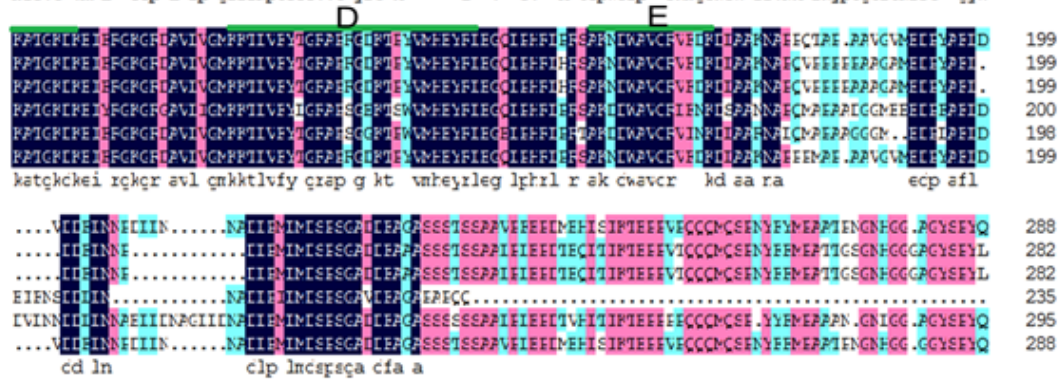

288
282
282
235
295
288

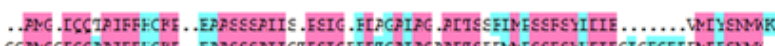

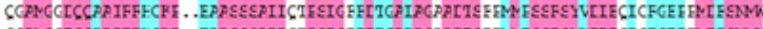

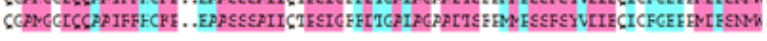

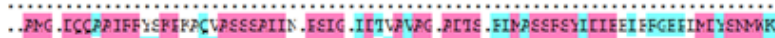

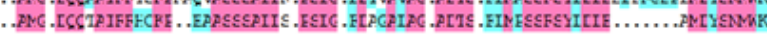

C

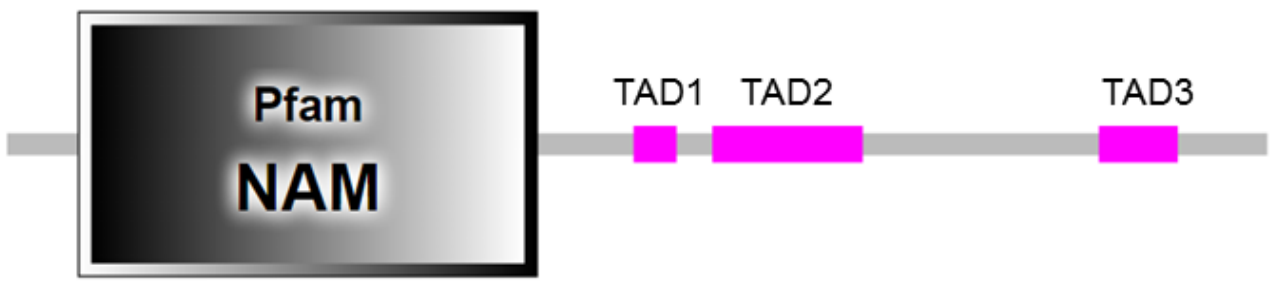

Fig1

\section{Figure 1}

Phylogenetic relationships among NAC proteins in plants, and the conserved NAM superfamily in TwNAC01. a. Neighbor-joining phylogenetic relationships between the TwNAC01 protein and NAC proteins in other plants. b. Amino acid sequence alignment analysis of the conserved homeodomain region of TwNAC01 with its closest homologs from barley, wheat, goatgrass, and durum wheat. c. The conserved NAM superfamily domain in the TwNAC01 protein. N, N-terminal NAC superfamily conserved domain; C, Cterminal transcriptional activation region; TAD, transcription activation domain. 


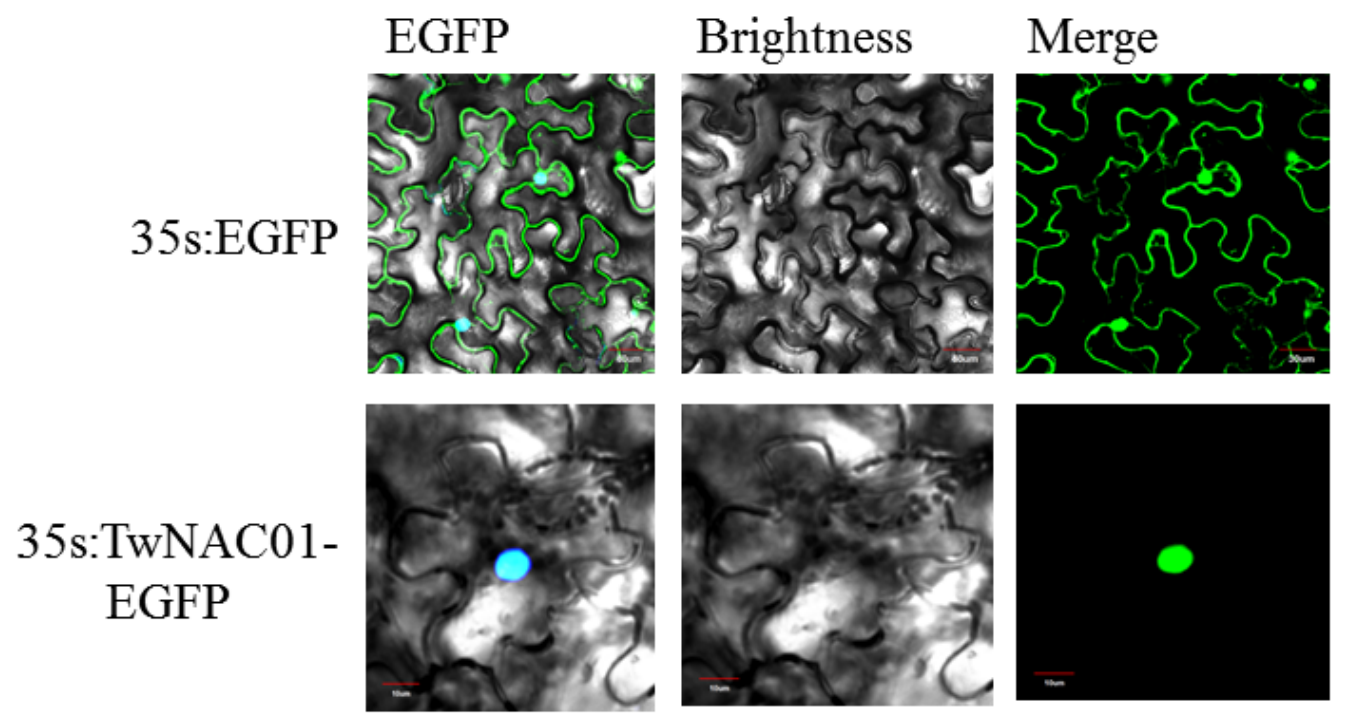

Fig 2

\section{Figure 2}

Subcellular localization of the TwNAC01 protein in the nuclei of tobacco cells. 

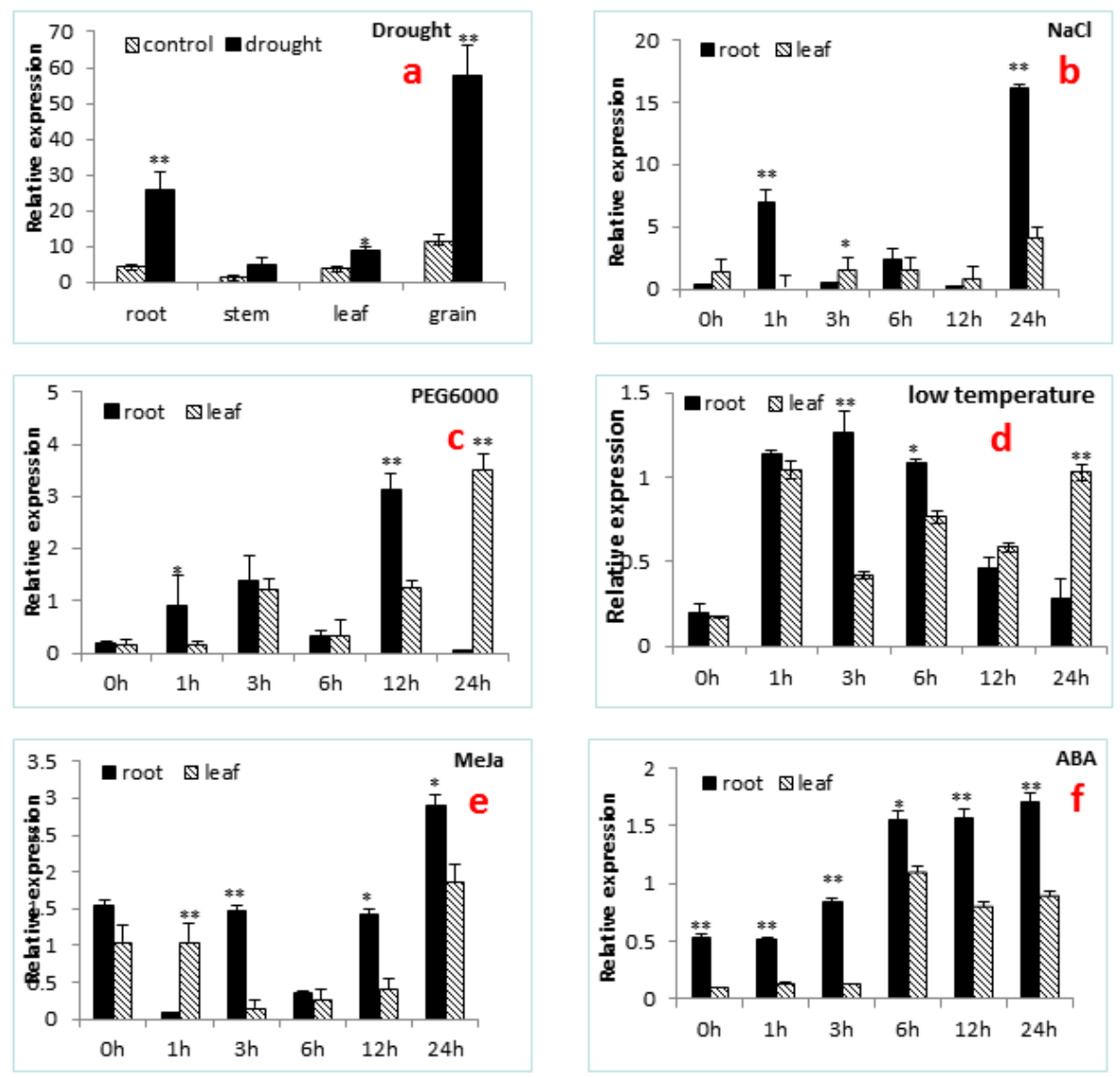

Fig 3

Figure 3

TwNAC01 gene expression patterns in triticale after stress treatments. Triticale plants were subjected to one of the following treatments: drought (A), $200 \mathrm{mM} \mathrm{NaCl}(\mathrm{B}), 20 \%$ PEG6000 (C), cold (4 $\left.{ }^{\circ} \mathrm{C}\right)(\mathrm{D}), 100 \mu \mathrm{M} \mathrm{ABA}$ $(E)$, or $100 \mu \mathrm{M}$ MeJA $(F)$. Relative expression levels in the plant tissues were determined using qRT-PCR and the 2- $\Delta \Delta C T$ method. Transcript levels were normalized to the wheat actin genes (TaActin). Values shown are the means $\pm S E$ of three replicates of three independent samples. Asterisks indicate statistically significant differences between the root and the leaf ( $\mathrm{P}<0.05$; $* * \mathrm{P}<0.01$ ). 

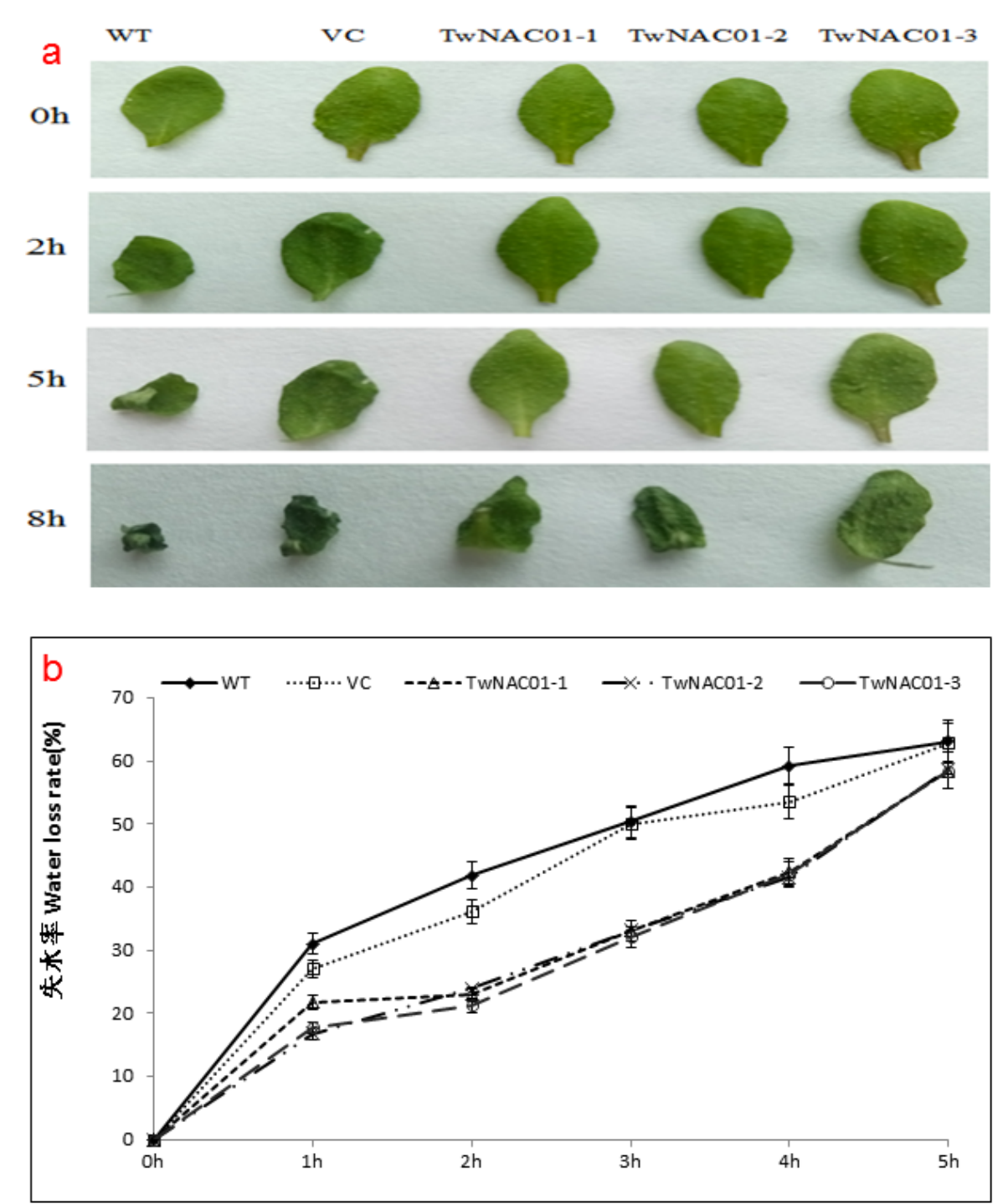

Fig 4

\section{Figure 4}

Three lines overexpressing TwNAC01 (TwNAC01-1, TwNAC01-2, and TwNAC01-3) exhibit reduced rates of water loss in the leaves. WT, VC (vector control). a. Leaves of various Arabidopsis lines after $0-8$ hours of dehydration. b. Rates of moisture loss in the leaves of various Arabidopsis lines. Values are means \pm SE of three replicates. Asterisks indicate statistically significant differences from the WT ( $\left.{ }^{* *} P<0.01\right)$. 

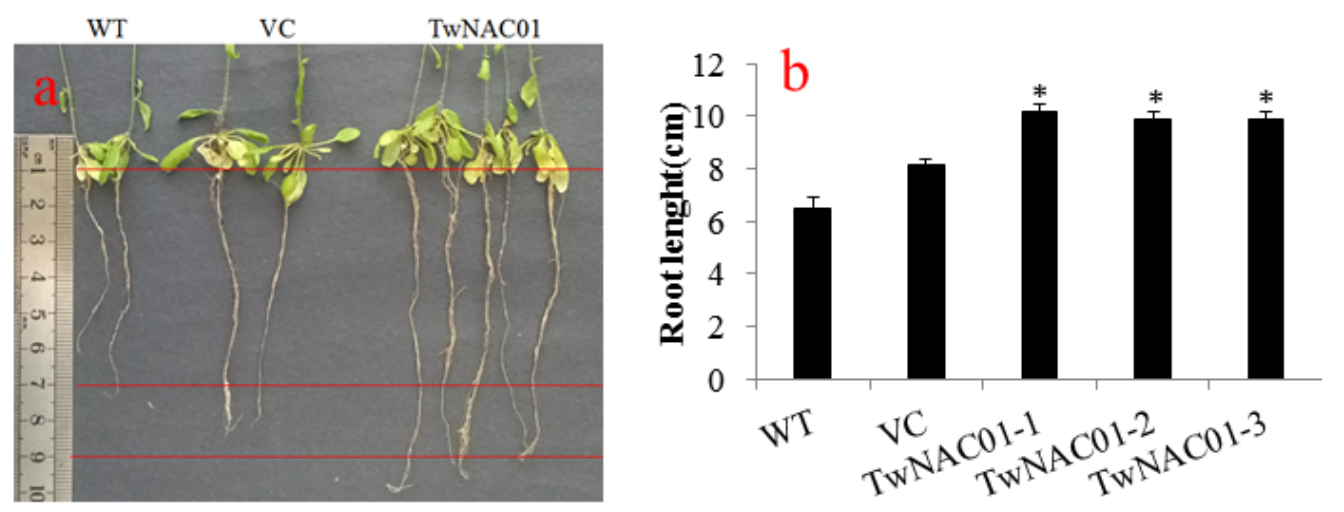

Fig 5

\section{Figure 5}

Root lengths in the WT, VC (vector control), and transgenic lines overexpressing TWNAC01. A. primary root length of WT, VC, and transgenic plants grown for $55 \mathrm{~d}$. b. Statistical analysis of the primary root lengths of WT, VC, and transgenic plants grown for $55 \mathrm{~d}$. Values shown are the means \pm SE of three replicates of three independent samples. Asterisks indicate statistically significant differences from the WT ( $\left.{ }^{*} P<0.05\right)$. 

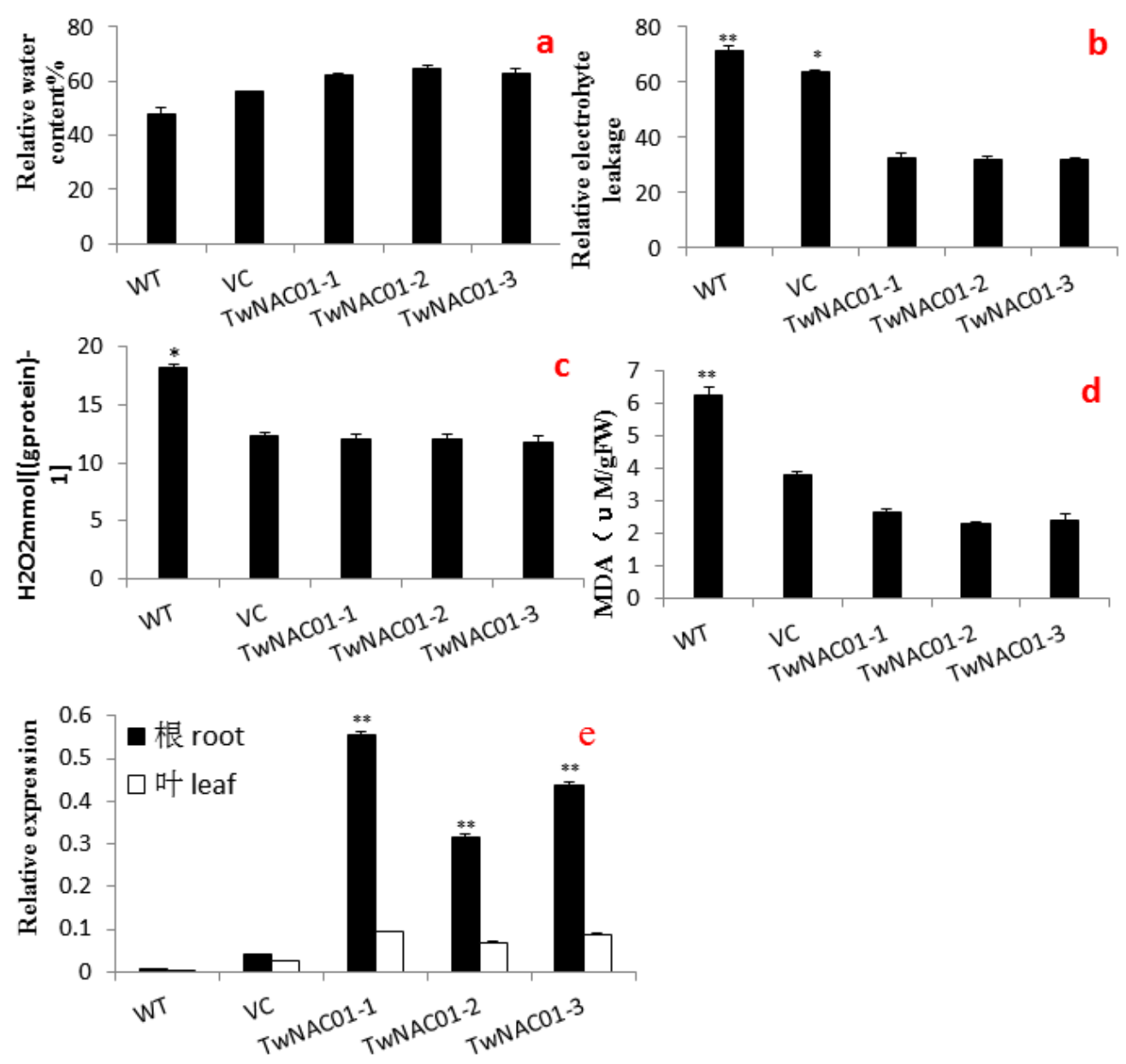

Fig 6

Figure 6

Analysis of physiological indices under drought stress conditions. Analyses of leaf relative water content (a), leaf electrolyte leakage, (b), H2O2 content (c), and MDA content (d) in WT and transgenic lines overexpressing TwNAC01 lines under normal and drought-stress conditions. Relative expression of TwNAC01 in the roots and leaves of transgenic Arabidopsis thaliana lines (e). Values are means \pm SE of three replicates. Asterisks indicate statistically significant differences from the WT $\left({ }^{*} P<0.05\right)$ 


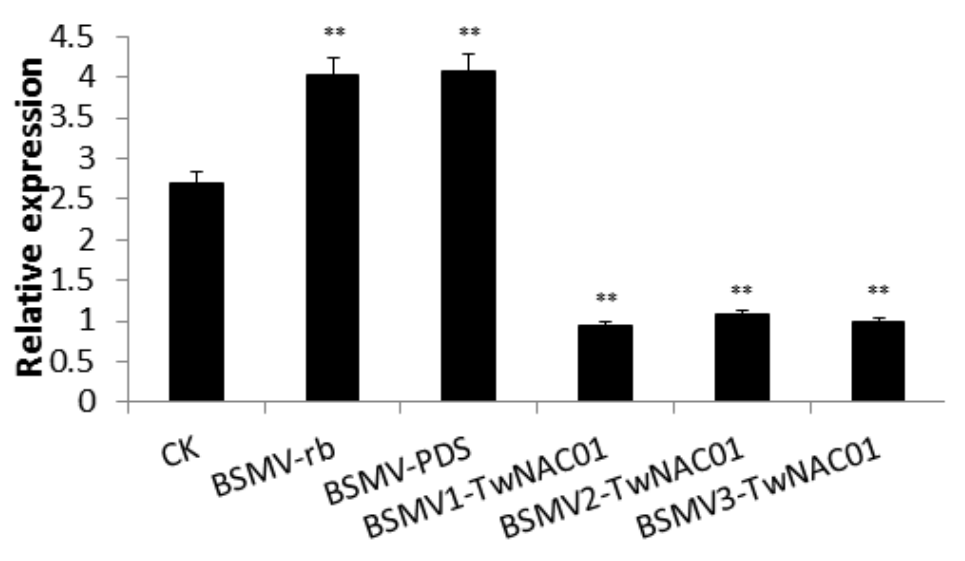

Fig 7

\section{Figure 7}

Relative TwNAC01 expression patterns in triticale after TwNAC01 gene silencing, as determined using qRTPCR and the 2- $\triangle \triangle C T$ method. Transcript levels were normalized to TaActin. CK, vector control; BSMV-yb, empty vector; BSMV-PDS, BSMV plus indicator gene; BSMV-TwNAC01, vector carrying silenced TwNAC01. Values shown are the means $\pm S E$ of three replicates of three independent samples. Asterisks indicate statistically significant differences from the CK (vector control) plants $(* P<0.05 ; \star \star P<0.01)$. 

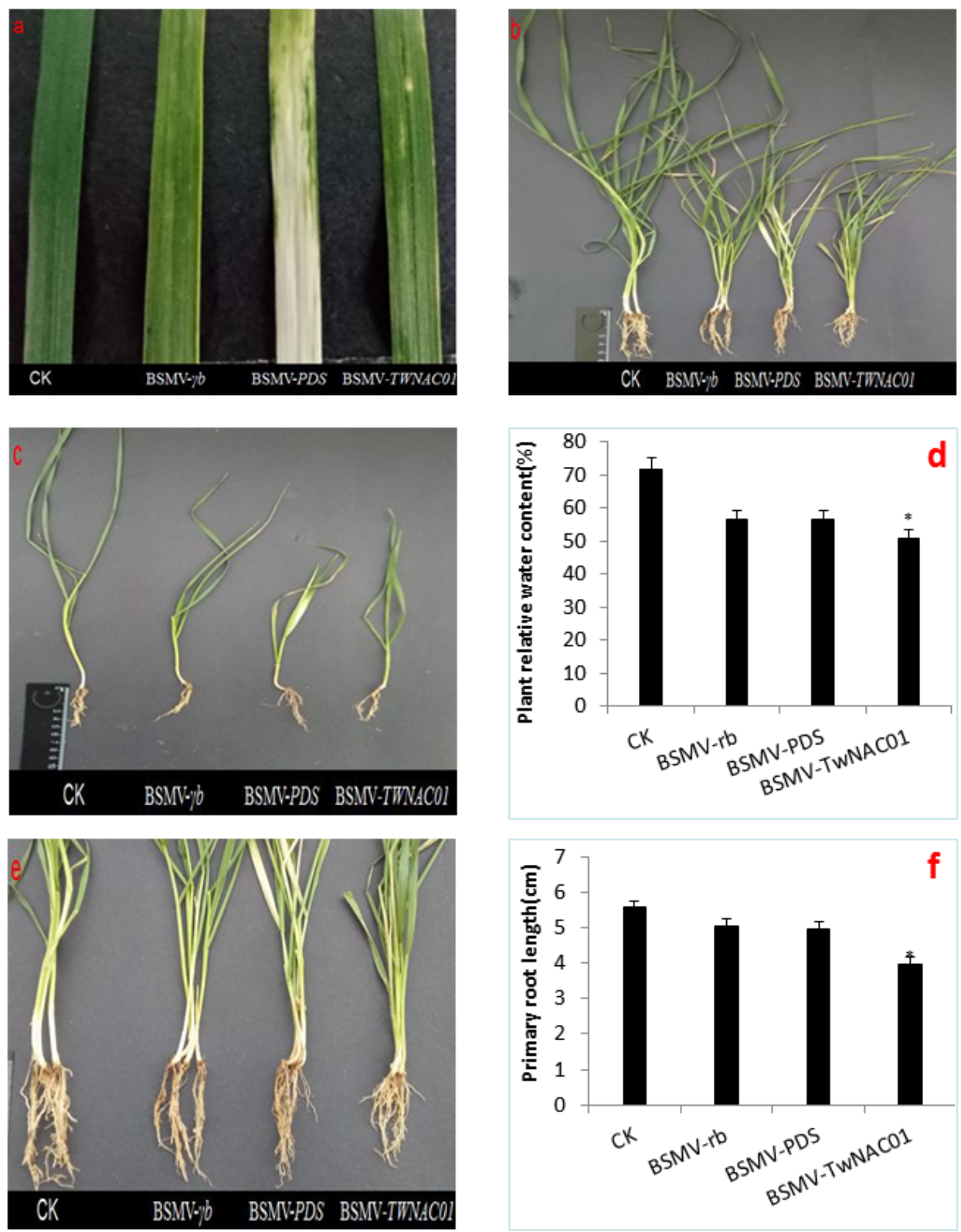

Fig 8

\section{Figure 8}

Phenotypic differences among triticale plants inoculated with different BSMV vectors for the VIGS of TwNAC01. a. Leaves, showing viral infection. b, c. Biomass comparison. d. Relative water contents. e. Root lengths, visual comparison. $f$. Root length quantification. Values shown are means $\pm S E$ of three replicates. Asterisks indicate statistically significant differences from control (uninfected) plants $(* \mathrm{P}<0.05$; $* \star \mathrm{P}<$ 0.01). CK, control; BSMV-yb, empty vector; BSMV-PDS, BSMV plus indicator gene; BSMV-TwNAC01, vector carrying silenced TwNAC01. 

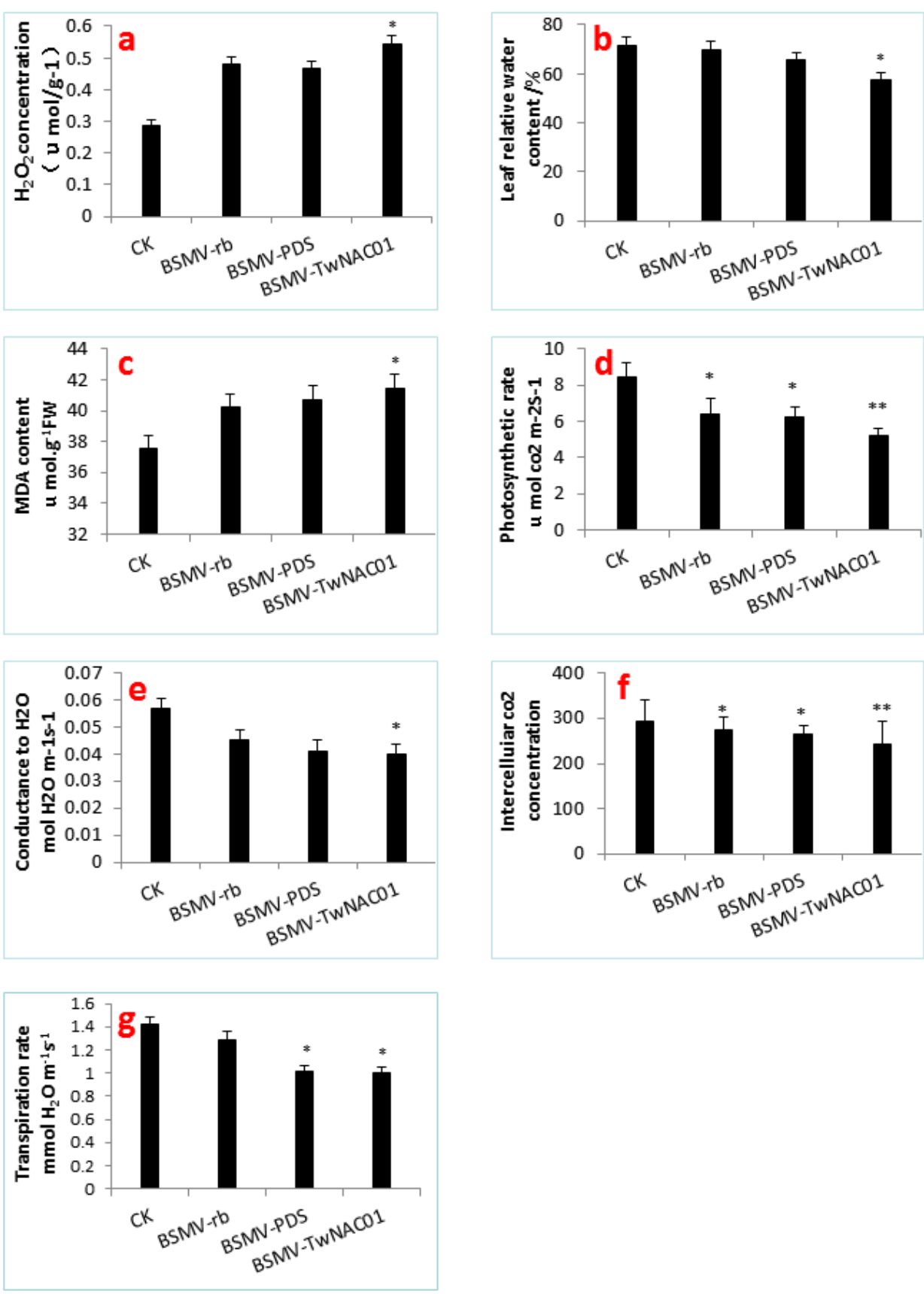

Fig 9

Figure 9

Physiological indexes of drought stress and photosynthesis in triticale leaves after virus-induced gene silencing using BSMV. a. H2O2 concentration. b. Relative water content (RWC). c. Malondialdehyde (MDA) content. d. Photosynthetic rate. e. Stomatal conductance to H2O. f. Intercellular CO2. g. Transpiration rate. Values shown are means \pm SE of three replicates. Asterisks indicate statistically significant differences from control (uninfected) plants ( $\mathrm{P}<0.05$; ${ }^{\star \star} \mathrm{P}<0.01$ ). CK, control; BSMV- $\gamma b$, empty vector; BSMV-PDS, BSMV plus indicator gene; BSMV-TwNAC01, vector carrying silenced TwNAC01. 


\section{Supplementary Files}

This is a list of supplementary files associated with this preprint. Click to download.

- renamed2055e.tif

- renamed99581.tif

- renameda4c76.tif

- renamed48fb0.tif

- renamed61028.docx 